Jadwiga Tomalkiewicz

\title{
STUDIES ON EDUCATION OF GEOGRAPHY TEACHERS IN POLAND
}

The researches carried out in Poland in the years 1978-1985 concerned mainly the graduates of pedagogy from departments of universities and higher schools, who were entering upon work in their profession. The purpose of the researches was to evaluate the level of abilities to solve psychological and pedagogical as well as objective and methodological problems of those who were beginning their profesional work. On this basis the evaluation of educational system of four-years' teachers' studies at universities and higher schools of pedagogy was to be made.

The researches were of a sounding character and they were carried out with the help of:

(1) A psycho-pedagogical test, which aimed at revealing the skills to solve didactic and educational situations, and was uniform for all pedagogical specializations.

(2) An objective-methological test (see Appendix), distinct for each pedagogical specialization, taking into consideration the specific character of each subject, and, at the same time, maintaining the uniformity of the problems under consideration, i.e.:

(a) the interpretation of the tèching contents;

(b) methodological problems;

(c) reading habit of literature concerning the subject and methodology.

This test was given to both teachers entering upon work and those with a long work time, recognized by the headmasters and inspectorsmethodologists as good and very good. The latter constituted the reference group for comparision of abilities to solve this type of problems by graduates.

(3) A questionnaire meant for graduates by means of which some information concerning social and living conditions of graduates, the course of studies, professional adaptation and others was gained.

(4) A questionnaire fo isters masters and workers of pedagogical control.

The sounding researches, conducted by the Departament of Didactics of Geography at Warsaw University in accordance with general methodology of researches, concerned the abilities to solve objective and methodo- 
logical problems and examined geography teachers-university graduates, starting their work and the teachers of comparative groups with five years' or more work time, recognized by the headmasters and pedagogical control as good and very good teachers.

The researches were carried out with the help of a test which was to make it possible to evaluate preparation of teachers to their job. As the basis for working out the test problems a list of abilities under examination was adopted. Those are for instance:

- the ability to define the aims and objectives of geography as a scientific discipline and the aims and objectives of geography as a school subject;

- the ability of teachers to define the cognitive, instructive and educational values of the subject "geography";

- the ability to make use of theoretical knowledge in solving particular didactic and educational situations;

- the ability to define characteristics of the subject being taughtgeography;

- the ability to detect difficulties in the geography teaching process, and the difficulties brought about by geographical teaching material;

- the ability to recognize practical values of geographical knowledge;

- the capability for self-education and improving one's skills through selection and utilizing literature from the domain of geography and the didactics of geography.

The test consisted of 10 open problems. The problems comprised issues which are typical of geography teaching (e.g. climate problems, natural environment protection, participation of Poland in social and political life of the world, and others).

At the selection of the essential contents of the problems it was assumed that the problems had to occur both in elementary and secondary schools and the answers could differ in the level of generality.

The test examined teachers from different, regions of the country. General results of the geography teachers test appear as follows:

The examined group

the result in per cent

average results

46.1

this including: university graduates

47.6

graduates of higher schools

of pedagogy

The comparative group

average result

The data above indicate that there are no essential differences in the methodological and objective preparation between university graduates and graduates of higher schools of pedagogy. 
The teachers from the comparative group obtained the average result $61.5 \%$, which is higher than the one of the examined group $46.1 \%$. This could be anticipated as the comparative group was entered by teachers with long work time and thus with long didactic experience. However, if we take into consideration the degree of difficulty in the problems, and these problems comprised essential and methodological points in basic degree, and the fact that the comparative group was selected (it was. entered into only by good teachers) while the selection in the examined group was random, then the comparison demonstrates the predominance of the young teachers.

The analysis of the solutions of particular test problems reveals a slight divergence in the level of arriving at them between the examined group and the comparative group. Only two problems were solved definitely better by the comparative group. They concerned the ability to define basic geographical notions and familiarity with methodological literature. Two other problems, which required from the tested persons the interpretation of geographical teaching material within the framework of general didactics, ivere solved at a very low level by both the examined and the comparative groups. These problems were meant to show the ability to evaluate geographical material in terms of difficulties which pupils may face while learning it, as well as familitary with the criteria of selecting geographical material for school programmes and handbooks.

The results obtained by geography teachers in the objective-methodological test do not diverge from those got by teachers of other specializations. Similarly, the geography teachers group does not show any clear differentiation in the level of professional preparation between graduates and good teachers. Furthermore, one cannot detect any statistically meaningful differences in the level of preparing to work between graduates of universities and higher schools of pedagogy.

The researches on psycho-pedagogical preparation demonstrated that the preparation level is the same in the graduates group, regardless of the type of university. It is not high as nearly $30 \%$ examined teachers obtained poor results. The comparison of test results indicates the predominance of young teachers and demonstrates their better preparation to didactic work than in the case of the comparative group.

Important information about graduates was gained with the help of the questionnaire. They consider that universities prepared them well to the teacher's job. They also notice, however, some deficiences in their preparation, especially in the domain of extradidactic work. They recognize their professional adaptation process as correct. Their questionnaire answers indicate that the choice in the teacher's job was made by them intentionally and consciously. In the light of the questioned teachers' opinions the problem of inspecting young teachers' lessons arose. This problem is brought about by neglecting by part of pedagogical control the role of inspections 
as a help in directing didactic and educational work of a teacher. Graduates find their essential preparation at university as satisfactory and most often they do not see any need to develop their knowledge in this direction. In this case there appears a divergence between the graduates' self-estimation and the evaluation of their essential preparation obtained by means of the objective-methodological test, which turned out relatively low.

In the final evaluation of the report it was acknowledged that the teachers' education system under consideration has sufficiently fulfilled its tasks but still a modification of this system, which would aim at improving practical preparation to solving teacher's problems, seems desirable. The conclusions drawn from this evaluation concern especially:

- introducing changes into the contents and methods of psychological and pedagogical preparation:

- increasing the role of pedagogical practice;

- intensification of methodological education and transfering a part of methodological classes to exercise schools;

- better preparation as far as the skill to operate technical educational devices is concerned.

The. above-presented conclusions from sounding researches concern the graduates of pedagogical departments of four-year studies and they are still current so they should be utilized in the students education at the reformed, five-year studies.

\section{APPENDIX}

\section{Test on subsiantial and methodological preparation of geography teachers}

We kindly ask you to answer frankly and possibly with all particulars the questions given below. Information will be used exclusively for the research purposes and will contribute to the improvement of the system of further education of teatchers of geographv itherefore, while answering you should rely upon your up-to-date knowledge without using any literature. You should complete the form within no more than 45 minutes.

1. Determine three groups of tasks and substantiate them on the example of the theme of the lesson "Polish climate".

2. Give short definition of the following notions:

(a) geographical environment,

(b) industrial region,

(c) card-diagram.

3. Determine the more important difficulties in teaching and learning geography resulting from the specific character of geographical material. 
4. Mentior and motivate the essential criterions of selection of geographical contents to the programmes and school manuals.

5. To which methods of protection and forming of geographical environment will you pay attention at the lesson: "Water Economy in Poland".

6. To which practical advantages of geographical knowledge do you attract

7. To which contents of other subjects taught do you refer at the geography lessons while carrying out the following themes:

(a) Types of rocks

(b) Geographical longitude and latitude

(c) Weather and its elements

(d) Economic cooperation of Poland with socialist countries.

Subject (s)

Contents

ad (a)

ad (b) .......

ad (c) $\ldots . . .$.

ad (d)

8. Determine major didactic problems of the repeated lesson on the theme: "Participation of Poland in the political and economic life of the world as well as three particular problems in order they cover fully the problem.

Major problem

Particular problems:

(a) .......

(b) $\ldots \ldots$

(c) .......

9. List three lately read works on didactics of geography and three works in geography.

Works in didactics of geography

Author

Title
(a) $\ldots . .$.
(b) $\ldots . .$.
(c) .......
(a) .......
(b) $\ldots . .$.
(c) .......

Works in geography

10. Which basic cognitive, instructive and educational values you attain teaching regional subject matter (characteristics of continents, states, lands and regions)?
(a) cognitive values:
(b) instructive values:
(c) educational values
Date: 


\section{REFERENCES}

S ł o m kiewicz, S., 1980, Funkcjonowanie zawodowe absolwentów nauczycielskich kierunków studiów (Professional functioning of graduates of pedagogical departments), Institute of Teachers' Pedagogical Education, a synthetic report of researches, typescript.

T o m a lk i e wi c z, J., 1984, „Przygotowanie zawodowe nauczycieli geografii absolwentów nauczycielskich kierunków dziennych" (Professional preparation of geography teachers, graduates of pedagogical studies), Geografia i wychowanie, MON, Warszawa. 